\title{
Clinical and Genetic Survey for Charcot-Marie-Tooth Neuropathy Based on the Findings in Turkey, a Country with a High Rate of Consanguineous Marriages
}

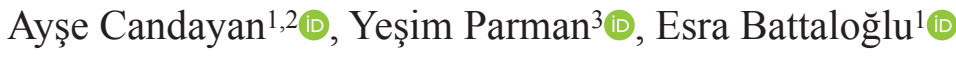 \\ ${ }^{1}$ Department of Molecular Biology and Genetics, Boğaziçi University, İstanbul, Turkey \\ ${ }^{2}$ VIB Center for Molecular Neurology, University of Antwerp, Antwerp, Belgium \\ ${ }^{3}$ Department of Neurology, İstanbul University İstanbul Medical School, İstanbul, Turkey
}

\begin{abstract}
Inherited peripheral neuropathies (IPNs) are a heterogeneous group of disorders of the peripheral nervous system. The most common type of IPN is Charcot-Marie-Tooth (CMT) disease, which constitutes an interesting research focus for neurologists and human geneticists alike. Most cases with CMT manifest with a slowly progressive symmetric distal weakness in the lower limbs that usually begin in the first to the third decade that causes atrophy and foot drop. Deep tendon reflexes are usually absent or reduced. A proven and efficient CMT therapy is yet available and may require different molecules and approaches due to its high clinical and genetic heterogeneity. Several ongoing clinical trials are promising and are mostly focused on the most frequent form, namely CMT Type 1A (CMT1A). Approximately, $60 \%$ of patients with CMT can be genetically diagnosed using the most advanced mutation screening techniques that cover approximately
\end{abstract}

100 IPN genes. Turkey has a $25 \%$ consanguineous marriage rate, and nearly $60 \%$ genetic diagnosis rate can still be reached when SH3 Domain and Tetratricopeptide Repeat Domain 2, Ganglioside-induced Differentiation-Associated Protein 1, and Histidine Triad Nucleotide Binding Protein 1 genes are also screened along with Myelin Protein Zero and Gap Junction Protein Beta-1 after exclusion of CMT1A duplication in families with probable recessive inheritance. The genetic diagnosis rates in different regions worldwide implicate that the most recent sequencing techniques should be more commonly used for both diagnosis and identification of further CMT genes. Herein, presented our 30 years of experience on genetic diagnosis and management strategies in CMT neuropathy in Turkey and review clinical and genetic features of this group of disorders.
Inherited peripheral neuropathies (IPNs) are a diverse group of disorders of the peripheral nervous system where neuropathy could be the only symptom or could be part of a multisystemic disorder. The most common type of IPN is Hereditary Motor and Sensory Neuropathy, a group of disorders that are more commonly called Charcot-Marie-Tooth (CMT) disease. ${ }^{1}$ The disease is named after the clinicians who originally reported the clinical features simultaneously in 1886, namely, French neurologist Jean-Martin Charcot, his student Pierre Marie, and British neurologist Howard Henry Tooth. ${ }^{2}$ CMT affects both motor and sensory axons, whereas motor axons are predominantly affected in hereditary motor neuropathy (HMN) and sensory and autonomic nerves in hereditary sensory/autonomic neuropathy. ${ }^{1}$ These three disorders represent a phenotypic continuum and are collectively termed CMT and related neuropathies. $^{3}$

\section{Clinical Features}

CMT is a clinically and genetically heterogeneous group of neurological disorders. Age of onset may be from birth to late adulthood and the symptoms may encompass a wide range of phenotypes. ${ }^{4}$ The hallmark of the disease is slowly progressive, symmetrical nerve degeneration, which results in chronic muscle weakness and wasting from the distal limbs ${ }^{4,5}$ as well as atrophy and foot drop. As the disease progresses, patients may develop distal upper limb weakness and skeletal deformities, such as pes cavus, hammertoes, and kyphoscoliosis, that are accompanying clinical features. Foot deformities may result in contractures, which cause further gait difficulties. Sensory symptoms are rare; however, they may be apparent in the neurological examination. Deep tendon reflexes are usually absent or reduced. ${ }^{2,45}$ Neuropathy is generally

Corresponding author: Esra Battaloğlu, Department of Molecular Biology and Genetics, Boğaziçi University, İstanbul, Turkey e-mail: batolog@baun.edu.tr

Received: November 4, 2021 Accepted: November 18, 2021 Available Online Date: January 18, 2022 • DOI: 10.4274/balkanmedj.galenos.2021.2021-11-13

Available at www.balkanmedicaljournal.org

ORCID iDs of the authors: A.C. 0000-0002-3528-2293; Y.P. 0000-0001-9793-6590; E.B. 0000-0003-3131-6123.

Cite this article as:

Candayan A, Parman Y, Battaloğlu E. Clinical and Genetic Survey for Charcot-Marie-Tooth Neuropathy Based on the Findings in Turkey, a Country with a High Rate of Consanguineous Marriages. Balkan Med J.; 2022; 39(1):3-11.

Copyright@Author(s) - Available online at http://balkanmedicaljournal.org/ 
easily diagnosed in patients who present with distal muscle weakness and sensory loss starting at the feet and slowly ascending to the knees and hands. However, the findings should also be confirmed with nerve conduction studies. ${ }^{2,6}$ Developmental history evaluation of the individual, such as delayed motor milestones, poor performance in sports, lag behind peers, and difficulty of shoe-fitting during childhood, is essential in the clinical history. ${ }^{1,6}$

Widespread population analyses on CMT epidemiology are still limited; therefore the true prevalence is currently speculative. Early estimates reported that 1 in 2500 individuals worldwide is affected by $\mathrm{CMT}^{7}$; however, most recent reports from different regions worldwide suggest variable prevalence rates. A systematic review on CMT epidemiology analyzed 802 studies and reported that CMT prevalence must be $9.7-82.3$ in 100.000 individuals worldwide with no ethnic predisposition. ${ }^{8}$

\section{Classification and Molecular Genetics}

The molecular genetic era in the CMT field began in 1982 with the identification of the first disease-causing locus. ${ }^{9}$ In 1991, came the discovery of a 1.4-Mb tandem duplication of a region on chromosome 17 containing the Peripheral Myelin Protein 22 (PMP22) gene, which was the first report of an individual CMT causative gene and was classified as CMT Type 1A (CMT1A). ${ }^{10}$ The Human Genome Project data publication and subsequent nextgeneration sequencing (NGS) technology advances at the turn of the century have led to a great acceleration in CMT discovery that causes genes and mutations. More than 90 causative genes have been reported at the time of writing. The genetic findings indicate that all modes of inheritance are possible for CMT, including autosomal dominant, autosomal recessive, X-linked, and maternal inheritance (Figure 1). The clinical and genetic heterogeneity of the disease is evident in observations and indicates different causative genes with similar clinical features or different mutations in the same gene with different disease subtypes, such as demyelinating and axonal pathologies. ${ }^{4}$ This second feature can be exemplified with Ganglioside-induced Differentiation-Associated Protein 1 (GDAP1) gene mutations that can be responsible for demyelinating form in one family but for axonal form in another. Even the same GDAP1 mutation, p.D149Y, may present with demyelination or axonal loss. ${ }^{11}$

CMT is a term for a group of multiple related neuropathies, thus a classification was required from the discovery of this disease. Historically, CMT is classified into two broad groups based on nerve conduction studies of patients. Decreased nerve conduction velocities suggest myelin dysfunction and are generally interpreted as nerve hypomyelination or demyelination, whereas decreased compound muscle action potential amplitudes suggest axonal damage and/or loss of nerve fibers. ${ }^{12}$ The clinical setting defined CMT1 as the demyelinating form of the disease, whereas CMT2 is the axonal form. ${ }^{4}$ The patients are diagnosed with demyelinating CMT (CMT1) when the upper limb motor nerve conduction

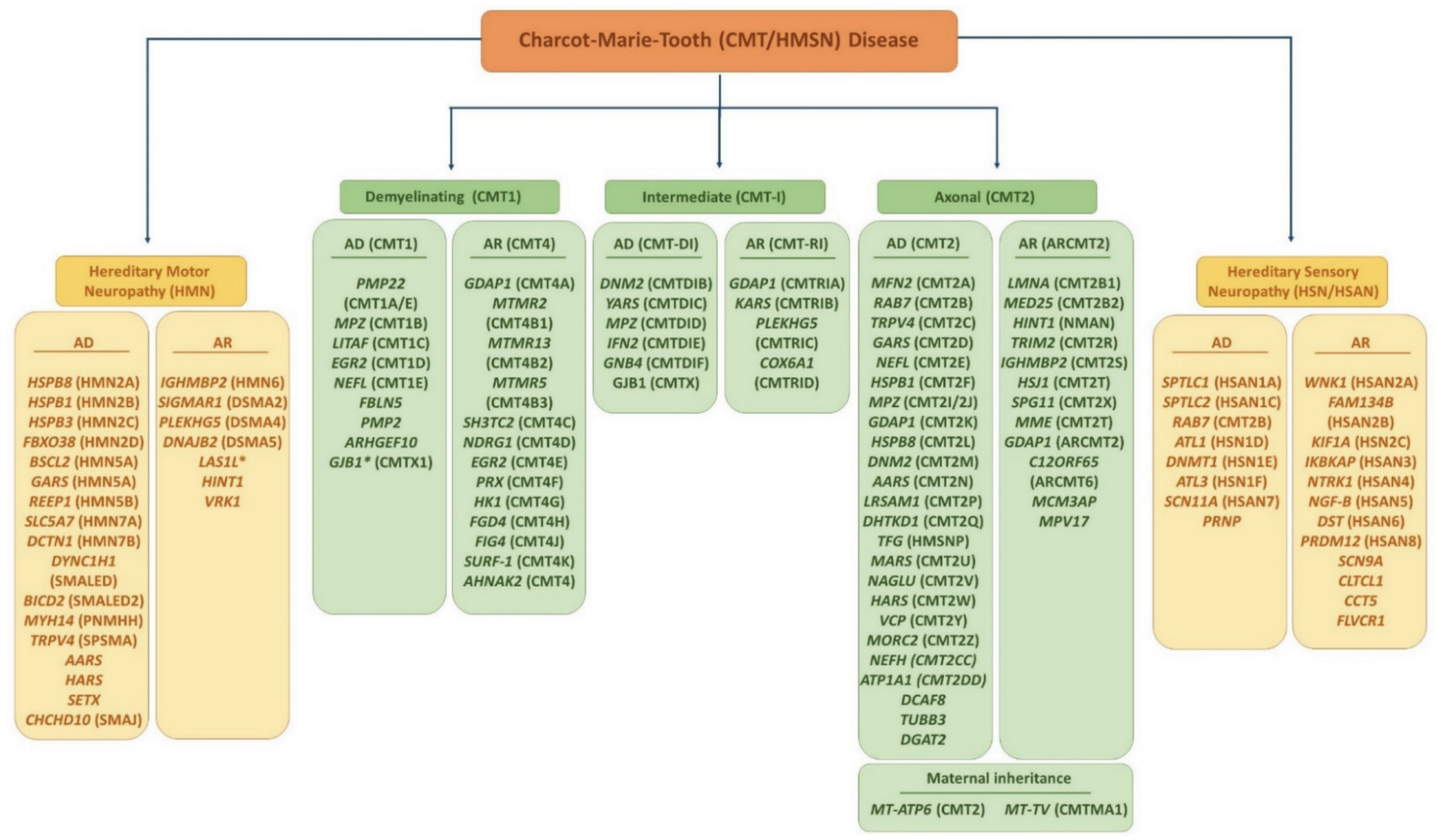

FIG. 1. An overview of subtype classification of Charcot-Marie-Tooth Disease and related neuropathies based on electrophysiological findings, inheritance pattern and causative gene.

CMT: Charcot-Marie-Tooth; AD: autosomal dominant; AR: autosomal recessive 
velocity ( $\mathrm{mNCV}$ ) is $<38 \mathrm{~m} / \mathrm{s}$, whereas the diagnosis is axonal CMT (CMT2) if $\mathrm{mNCV}$ is $>38 \mathrm{~m} / \mathrm{s}$ with reduced compound muscle action potential amplitudes (4). Later, a new subtype was defined as "intermediate CMT" (CMT-I) for patients with an upper limb $\mathrm{mNCV}$ of $25-45 \mathrm{~m} / \mathrm{s}^{13}$ Both axonal and demyelinating disease types will eventually result in an axonal loss in the later stages. ${ }^{14}$

Following the advancements in the field of human genetics, the identification of causative genes for CMT led to a further subclassification that combines electrophysiological findings, inheritance patterns, and causative genes. ${ }^{15}$ Accordingly, CMT1 and CMT4 groups consist of demyelinating types of the disease with dominant and recessive inheritance, respectively, whereas CMT2 and Autosomal Recessive Axonal Charcot-Marie-Tooth Disease (ARCMT2) consist of axonal types of the disease with dominant and recessive inheritance, respectively. Moreover, causative genes are reflected in disease nomenclature with a certain letter for each gene. Figure 1 gives an overview of this common classification. Nevertheless, the advent of NGS technologies greatly accelerated the gene discovery rate, causing this classification to become less straightforward. The issue became even more complicated with discoveries that suggest that different mutations in the same gene may have different inheritance patterns or may cause different CMT phenotypes as in the case of GDAPI mutations. ${ }^{16,17}$ Recently, a new classification system was proposed to include all known information on a case, such as inheritance type, phenotypical disease form, and the causative gene using abbreviations for each. ${ }^{18}$

Nonetheless, this new classification system has not been fully implemented in the field yet.

This study aimed to review the clinical and genetic aspects of different CMT subtypes below and share our data accordingly for each of these forms. Our cohort consists of $>1350$ patients with IPN; however, clinical CMT diagnosis was confirmed in 645 cases. Of whom, 459 cases (71\%) presented with demyelinating and 186 $(29 \%)$ with the axonal form of the disease.

CMT1: CMT1 is defined as a dominantly inherited demyelinating subtype of the disease. In this disease form, the Schwann cell function and myelin sheath formation are affected. ${ }^{1,4}$ The most common type of CMT1 is CMT1A, which is approximately $70 \%$ of all demyelinating cases and $40 \%$ of all CMT cases. ${ }^{1} \mathrm{CMT} 1 \mathrm{~A}$ is caused by a $1.4 \mathrm{Mb}$ tandem duplication of chromosome $17 \mathrm{p} 11.2$, which includes the PMP22 gene. ${ }^{10}$ Deletion of the same region on chromosome $17 \mathrm{p} 11.2$ results in Hereditary Neuropathy with Liability to Pressure Palsies (HNPP). ${ }^{19}$ Point mutations in the PMP22 gene are also disease-causing in $1-5 \%$ of demyelinating cases and this subtype is termed CMT1E. ${ }^{1,6}$ Other common disease-causing genes in CMT1 include Gap Junction Protein Beta-1 (GJB1) on the X-chromosome (Xq13.1) causing CMTX1 and Myelin Protein Zero $(M P Z)$ on chromosome 1 causing CMT1B. CMTX1 has a prevalence of approximately $10 \%$ among demyelinating cases, with males being more severely affected than females possibly due to random X-inactivation. ${ }^{20,21}$ Contrarily, CMT1B cases are approximately $5 \%$ of all CMT cases. ${ }^{6}$ Other CMT 1 causative genes include LITAF (CMT1C), EGR2 (CMT1D), NEFL (CMT1F),
FBLN5, and PMP2 (CMT1G) that are rarely mutated. ${ }^{3}$

In our population, genetic studies revealed the same frequencies of these gene mutations in which CMT1A duplication (151 cases) is followed by X-linked form (GJB1 mutations in 47 cases), then by $M P Z$ (6 cases), and finally by PMP22 (3 cases). The rest of the CMT1 genes have either one or no patients. Another four patients with PMP22 mutations presented with HNPP. The distribution of CMT gene mutations in our cohort of 645 cases is summarized in Figure 2.

CMT2: The dominantly inherited axonal disease form is called CMT2. The causative genes in this subtype have predominant impacts on neuronal function, metabolism, and maintenance and their mutations result in axonal degeneration. ${ }^{1,4}$ The axonal subtype of the disease is less common than demyelinating types. ${ }^{8}$ Both dominant and recessive axonal CMT is caused by many but rarely mutated genes that are reported in a small number of families. ${ }^{22}$ Pathogenic mutations in Mitofusin 2 (MFN2) gene on chromosome 1p36.22 makes up the most common cause of CMT2 with a prevalence of nearly $20 \%$ in all axonal cases. ${ }^{23}$ Heterozygous mutations in the MFN2 gene are classified as CMT2A2 $\mathrm{A}^{23}$, whereas a rare and more severe disease form called CMT2A2B is caused by homozygous or compound heterozygous mutations in the same gene. ${ }^{24}$ Other CMT2 genes include KIF1B (CMT2A1), RAB7 (CMT2B), TRPV4 (CMT2C), GARS (CMT2D), NEFL (CMT2E), HSPB1 (CMT2F), GDAP1 (CMT2K), HSPB8 (CMT2L), DNM2 (CMT2M), and $A A R S(\mathrm{CMT} 2 \mathrm{~N}){ }^{3}$

Our cohort includes 15 patients with MFN2 gene mutations, with only two patients having homozygous mutations in this gene. The rarity of homozygosity for MFN2 mutations even in a population with a high rate of consanguinity, as in the case of our population, may indicate a considerably high rate for de novo mutations in this gene at the population level. Our studies mostly focused on CMT1 and in general on recessive cases, thus a high number of CMT2 cases were not analyzed. Still, two cases were identified with $N E F L$, two cases with $H S P B 1$, and single cases with $K I F 1 B$, $D N M 2$, and $A A R S$ mutations. Among all cases with GDAP1 mutations, only one case had a heterozygous causative mutation, indicating the presence of dominant axonal CMT (CMT2).

CMT4: The demyelinating and recessively inherited CMT subtype is termed CMT4. This is a very rare and genetically highly diverse subtype. ${ }^{25}$ These patients almost always have very severe clinical phenotypes with early onset of symptoms. ${ }^{2}$ Homozygous mutations in GDAP1 cause CMT4A, which is the most common subtype among CMT4. This is followed by mutations in SH3 Domain and Tetratricopeptide Repeat Domain 2 (SH3TC2) causing CMT4C. ${ }^{26}$ Other genes causing recessive demyelinating CMT include MTMR2 (CMT4B1), MTMR13/SBF2 (CMT4B2), MTMR5/SBF1 (CMT4B3), NDRG1 (CMT4D), EGR2 (CMT4E), PRX (CMT4F), HK1 (CMT4G), FGD4 (CMT4H), and FIG4 (CMT4J). ${ }^{3}$

Our cohort with demyelinating phenotype has SH3TC2 as the most commonly mutated gene with 17 cases. GDAP1 mutations were associated with demyelinating disease form in nine patients. Additionally, four of these cases had c.786delG mutation, reflecting 


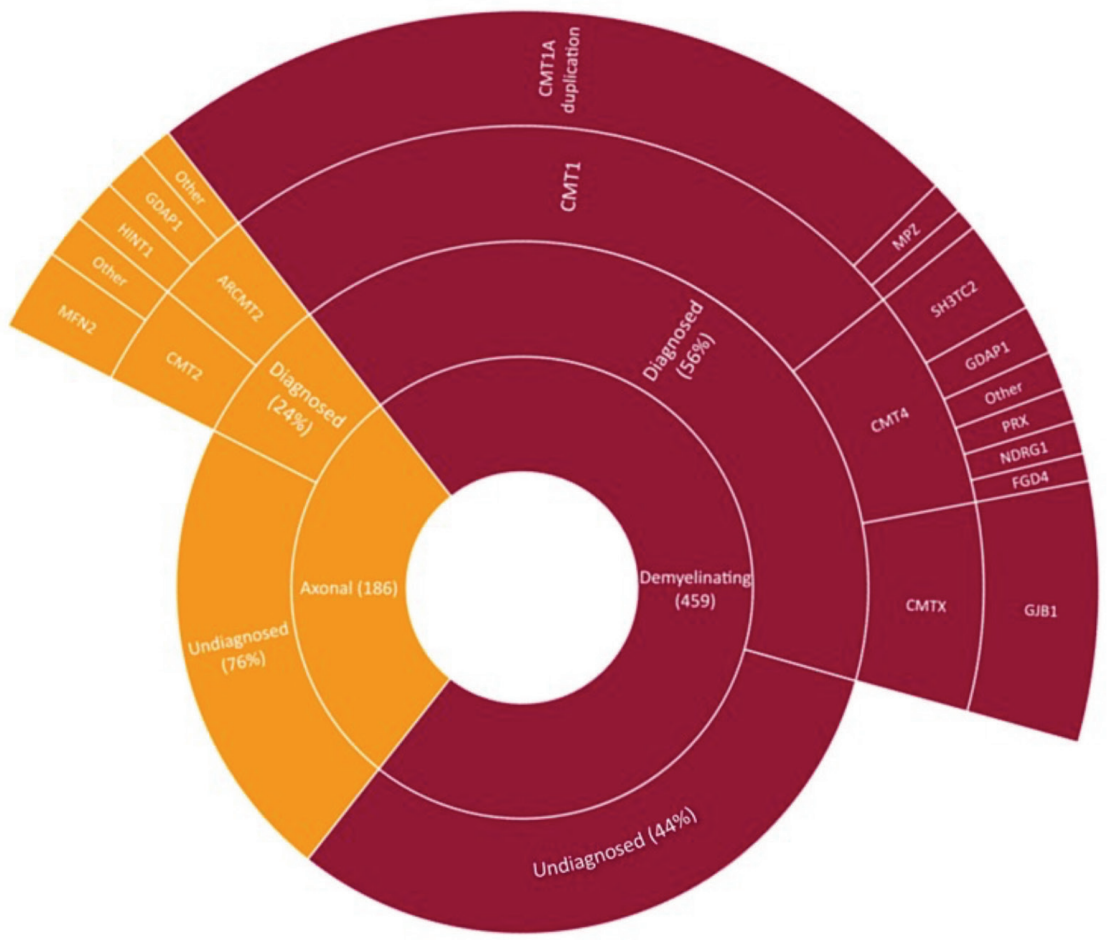

\begin{tabular}{|c|c|c|}
\hline $\begin{array}{c}\text { Disease subtypes } \\
\text { Demyelinating } \\
\text { CMT1A }\end{array}$ & Gene name & Number of patients \\
\hline CMT1B & CMT1A duplication & 151 \\
\hline CMT1E & MPZ & 6 \\
\hline CMTX & PMP22 & 3 \\
\hline CMT4A & GJB1 & 47 \\
\hline CMT4B1 & GDAP1 & 9 \\
\hline CMT4B2 & MTMR2 & 2 \\
\hline CMT4C & SBF2/MTMR13 & 4 \\
\hline CMT4D & SHTTC2 & 17 \\
\hline CMT4F & NDRG1 & 6 \\
\hline CMT4G & PRX & 6 \\
\hline CMT4H & HK1 & 1 \\
\hline Axonal & FGD4 & 5 \\
\hline CMT2A & MFN2 & 15 \\
\hline CMT2A1 & KIF1B & 1 \\
\hline CMT2E & NEFL & 2 \\
\hline CMT2F & HSPB1 & 2 \\
\hline CMT2K & GDAP1 & 1 \\
\hline ARCMT2K & GDAP1 & 8 \\
\hline CMT2M & DNM2 & 1 \\
\hline CMT2N & AARS & 1 \\
\hline NMAN & HINT1 & 8 \\
\hline & GAN & 2 \\
\hline & SORD & 2 \\
\hline & MCM3AP & 1 \\
\hline Total diagnosed & SACS & 1 \\
\hline & & 302 \\
\hline
\end{tabular}

FIG. 2. Distribution of demyelinating and axonal phenotypes and mutations in the cohort of 649 Turkish patients with Charcot-Marie-Tooth disease.

CMT: Charcot-Marie-Tooth

the possibility of a founder effect. The second most commonly mutated genes were $P R X$ and $N D R G 1$ with six cases each, followed by FGD4 (5 cases), MTMR13/SBF2 (4 cases), MTMR2 (2 cases), and a single case of $H K 1$.

ARCMT2: The recessively inherited axonal CMT disease is a very rare subtype termed ARCMT2. ${ }^{1}$ Mutations in Histidine Triad Nucleotide Binding Protein 1 (HINT1) are disease-causing in approximately $10 \%$ of all recessive CMT cases. Interestingly, this gene is responsible for nearly $80 \%$ of axonal neuropathy cases that present with neuromyotonia. ${ }^{27,28}$ Other genes that cause ARCMT2 include $L M N A$ (CMT2B1), MED25 (CMT2B2), TRIM2 (CMT2R), IGHMBP2 (CMT2S), HSJ1 (CMT2T), SPG11 (CMT2X), MME, GDAP1, and C12ORF65. ${ }^{3}$

HINT1 gene mutations were identified in eight families among the patient with ARCMT2 in our cohort based on presentation with neuromyotonia. The most commonly mutated gene in our ARCMT2 cohort was GDAP1 with nine families presenting axonal neuropathy. Two families had GAN and another two had SORD gene mutations. Single cases with mutations in $S P G 11, M M E$, and C12ORF65, MCM3AP, and SACS were also identified.

CMT-I: CMT cases with mNCV values of $25-45 \mathrm{~m} / \mathrm{s}$ are classified as CMT-I. ${ }^{13}$ Median NCV values may be different in different nerves of the same patients or among other affected family members. ${ }^{1}$ Disease-causing genes in CMT-I may be dominantly (CMT-DI) or recessively (CMT-RI) inherited, which include $M P Z, G J B 1$, DNM2 (CMTDIB), YARS (CMTDIC), IFN2 (CMTDIE), GNB4 (CMTDIF), GDAP1 (CMTRIA), KARS (CMTRIB), PLEKHG5
(CMTRIC), and COX6A1 (CMTRID). ${ }^{3}$ None of our cases with $M P Z$ mutations, but almost all cases with GJB1 mutations had $\mathrm{mNCV}$ values of $25-45 \mathrm{~m} / \mathrm{s}$. Almost all axonal cases with GDAP1 mutations had mNCV values in this range. Thus, they can be accepted as CMT-I, as well as CMT1 or CMT2.

\section{Molecular Mechanisms Leading to Charcot-Marie-Tooth Disease}

Demyelinating and axonal forms of the disease may be clinically distinguished using nerve conduction studies, but pathologies are also well-established to eventually converge into a final pathway, which results in axonal degeneration and muscle denervation. ${ }^{14}$ The pathology may either be due to mutations that alter nerve function or their proper myelination. The influence of these genes in disease progression is another focus in CMT research. The genes implicated in CMT pathogenesis belong to a vast range of functional classes, including structural components of myelin, signaling proteins, proteins in mitochondrial dynamics, cytoskeletal proteins, and proteins in axonal transport. Understanding the molecular mechanisms is important since they may provide molecular targets for therapeutic approaches.

CMT1A, as the most common subtype, has historically been the leading subject in experimental research. The discovery that the duplication of the 17p11.2 locus causes CMT1A, and its deletion causes HNPP, made it clear that a gene-dosage mechanism was responsible for the pathology. The PMP22 gene located in this locus produces a small integral membrane protein in Schwann 
cells, which is a major myelin component. ${ }^{29}$ Similarly, MPZ, the causative gene for $\mathrm{CMT} 1 \mathrm{~B}$, encodes for a transmembrane protein that makes up $>50 \%$ of all proteins purified from the myelin sheaths. ${ }^{30}$ The myelin may be destabilized when the ratio between $P M P 22$ and MPZ gene products is altered. ${ }^{31}$ The Pmp22null mice have myelination to some extent; however, frequent tomacula formation was observed in nerve biopsies. ${ }^{32}$ Contrarily, observations in $M p z-n u l l$ mice suggest that $M P Z$ is essential for myelination and membrane compaction. ${ }^{33}$ An interesting finding implicated that overexpressed PMP22 causes formation of ubiquitinated aggregates in late endosomes both in vitro and in vivo. Cellular response against misfolded proteins showed to be the cause of perturbed Schwann cell function due to overloaded protein degradation machinery. ${ }^{34}$ Another breakthrough discovery made through CMT1A, CMT1B, and CMTX mouse models revealed that immune cells, particularly $\mathrm{T}$ cells and macrophages, were involved in demyelination during disease progression, perhaps while attempting to repair myelin defects due to pathogenic mutations. ${ }^{35,36}$

Peripheral neurones have exceptionally long axons that require high energy and regular transport of specific cargo; therefore, healthy mitochondria and proper axonal transport are essential for these cells. Mitochondrial dynamics, a collective term for mitochondrial fusion and fission, describes the regulation of shape, size, number, and transport of mitochondria, which is fundamental for the proper distribution of these organelles along the axons. ${ }^{37}$ Numerous CMT causative genes are implicated in this regulation, among which MFN2 and GDAP1 are the most well-established genes. MFN2, together with $M F N 1$, regulates mitochondrial fusion, whereas GDAP1 regulates mitochondrial fission. Pathogenic mutations in these genes lead to improper distribution of these organelles and/ or abnormally shaped mitochondria, which are likely incapable of performing fundamental tasks. Therefore, cytosolic calcium imbalance and increased oxidative stress occur, leading to axonal degeneration and neuronal death. ${ }^{37,38}$

Axonal transport of vesicles and organelles along microtubules is also essential for proper neurone function. As expected, axonal neuropathy is observed due to mutations in important members of the neurofilament family (NEFL and NEFH genes). ${ }^{39,40}$ Additionally, $R A B 7$, which encodes for a protein that acts as a regulator of vesicular transport, also causes axonal CMT. ${ }^{41}$ Similarly, the DNM2 gene, underlying intermediate CMT, encodes for a protein involved in receptor-mediated endocytosis, actin assembly, and membrane trafficking. ${ }^{42-44}$ Mutations in the heavy chain of dynein motor protein $(\mathrm{DYNC} 1 \mathrm{H1})$ and in a part of a multi-subunit complex protein, which binds dynein (DCTN1), are associated with axonal CMT and distal HMN, respectively. ${ }^{45,46}$ Both DYNC1H1 and DCTN1 were vital for microtubule-mediated axonal transport. ${ }^{47}$ Moreover, HSPB1, HSPB3, and HSPB8 coding for small heat shock proteins were also associated with axonal CMT and distal HMN. They act as molecular chaperones and may be involved in actin and intermediate filament assembly. ${ }^{48-50}$ The identification of numerous CMT genes that are involved in cytoskeletal function and assembly further implies axonal transport dysregulation as a common disease mechanism.

\section{Genetic Diagnosis Strategies in Charcot-Marie-Tooth Disease}

Correct molecular diagnosis of inherited neuropathies can only be achieved by active communication between clinicians and molecular geneticists. Once a neuropathy diagnosis is established by clinical examination and electrophysiological findings, looking for evidence of a genetic origin is the next step. Clues for genetic origin are relatively easy to find in large families with multiple cases but could be challenging in isolated cases or adopted individuals. ${ }^{6}$ Therefore, family history should be thoroughly investigated with specific questions on developmental milestones of the affected individual and their physical performance in childhood. Acquired neuropathy could be distinguished from genetic neuropathy using clinical markers, such as asymmetrical weakness, specific electrophysiological clues, magnetic resonance imaging, and cerebrospinal fluid protein level. ${ }^{6}$ The patient should be referred to molecular diagnosis only with suspicious inherited neuropathy. Genetic testing should not be offered to eliminate the possibility of an inherited neuropathy since the causative gene and mutation cannot be identified even in $>40 \%$ of inherited cases due to its heterogenic nature. Additionally, it causes unnecessary labor and financial loss.

Multiple tools are available for genetic testing in CMT disease. One should address several issues to correctly choose a strategy. Initially, the likely mode of inheritance must be determined. Autosomal recessive inheritance is likely with multiple affected individuals in the same generation and/or parental consanguinity in the pedigree. X-linked inheritance is excluded in male-tomale transmission. In more challenging pedigrees, such as small families and sporadic cases, autosomal dominant or de novo dominant inheritance are considered in Northern Europe and North America, whereas in regions with high consanguinity rates, like Turkey, autosomal recessive inheritance can still be possible. ${ }^{6}$ Axonal neuropathy with strict maternal inheritance indicates mitochondrial DNA mutations. ${ }^{51,52}$ Meanwhile, informing the molecular geneticist on the axonal or demyelinating pathology or predominantly motor, sensory, or both pathology is crucial since these different phenotypes, alongside other indicators, may direct the geneticist to look for certain genes. ${ }^{6}$

Sequential screening of known genes: Genetic testing strategies based on mutational frequency have been suggested by multiple studies, which use sequential screening of most causative genes based on clinical features of patients. ${ }^{15,20,53,54}$ This is generally a high-yield-low-cost strategy since several genes are responsible for a great number of cases..$^{15}$ For instance, PMP22 duplication is shown to be responsible for nearly $40 \%$ of all CMT cases, thus it is the initial target for molecular testing. ${ }^{20,54}$ When the patient has demyelinating neuropathy and is negative for $P M P 22$ duplication, testing for $G J B 1$ mutations is reasonable without the male-to-male transmission in the pedigree and followed by testing for $M P Z$ mutations. For axonal neuropathy cases, mutations in the MFN2 gene could be initially screened. ${ }^{20}$ Studies that retrospectively analyze large patient cohorts revealed that mutations in four genes (PMP22, MPZ, GJB1, and MFN2) were the underlying cause in $>90 \%$ of all diagnosed CMT cases. ${ }^{55-57}$ Therefore, initial screening 
of these four genes before moving to more advanced tools is highly advised. ${ }^{57}$ Additionally, certain genes could be considered for initial screening when the patient has some distinct clinical features. For instance, neuromyotonia is established as a very frequent symptom in patients with recessive axonal neuropathy with causative mutations in the HINT1 gene. ${ }^{28}$ Likewise, patients with demyelinating neuropathy with $S H 3 T C 2$ mutations frequently present with scoliosis or kyphoscoliosis. ${ }^{58}$ Similarly, diaphragmatic dysfunction and vocal cord paresis are frequently observed in patients with GDAP1 mutations. ${ }^{59}$ Therefore, initial screening of these genes may be pivotal in patients with relevant modes of inheritance and clinical features.

NGS: Sequential screening strategy may be time- and costeffective in demyelinating cases; however, the presence of many individually rare disease-causing genes in axonal neuropathies may cause the procedure to become very expensive and cumbersome. ${ }^{6}$ The development and commercialization of NGS technologies caused a shift in the trend for genetic diagnosis strategies. High-throughput DNA sequencing, more commonly referred to as NGS, describes the massively parallel sequencing of DNA fragments. ${ }^{60}$ This technology is an upgrade to the first generation of DNA sequencing (Sanger sequencing) and generates sequence data using "sequencing by synthesis." This method utilizes initial random shearing of genomic DNA and capture of sheared fragments in separate chambers or through adaptors, followed by the amplification of fragments using modified nucleotides. Finally, short-read sequence data are generated by detecting incorporated nucleotides on each synthesis round. ${ }^{60}$

NGS technologies may be used for whole-genome sequencing (WGS), for targeted sequencing of certain genes/loci in the genome (gene panels), or sequencing of only the protein-coding regions of the genome termed, whole-exome sequencing (WES). ${ }^{6}$ NGS technology choice will depend on the purpose of the analysis. When using gene panels, high-quality sequence data will be obtained by screening a small set of genes, which allows easy genetic diagnosis if the patient has a pathogenic mutation in one of the genes present in the gene panel. Using WES, sequencing data with relatively less read-depth will be obtained from a large set of genes, and this unbiased sequencing technique identifies novel causative genes in individuals without a recurrent gene mutation. ${ }^{6}$

Currently, the use of gene panels is the common practice in large diagnostic centers for the sequencing of recurrent genes in the molecular diagnosis of CMT disease. ${ }^{61-65}$ CMT panels covering genes associated with its specific subtypes are increasingly discouraged due to the presence of phenotypically overlapping features between different CMT subtypes and neurological disorders, such as inherited ataxias, hereditary spastic paraplegias, and distal myopathies. ${ }^{63}$ Nevertheless, the development of large gene panels, including all known CMT-causing genes, will drastically reduce costs for sequencing and improve the characterization of genotype-phenotype correlation in CMT. Moreover, gene panels will likely unveil less common inheritance patterns, such as digenic inheritance. ${ }^{4}$ The gene hunt for CMT disease is not over, thus the gene panels currently do not have full coverage of all relevant genes and loci and are not widely commercially available. However, this technology is shortly expected to entirely replace sequential Sanger sequencing.

According to our experience, the most effective approach in CMT molecular diagnosis is to use sequential sequencing after excluding CMT1A duplication and then WES or WGS as the last step. Sequential screening can be substituted with a panel to screen for most commonly mutated CMT genes; however, it would be more expensive compared to sequential screening. In Turkey, just considering recessive cases, both demyelinating and axonal forms reached a $60 \%$ success rate in molecular diagnosis with initial screening for GDAP1 mutations followed by WES. Initial filtering of the WES data with relaxed filtering criteria (MAF < 0.05 ) for known neurology disease genes has a major contribution to the success rate since it identifies the mutations in the genes that overlap with other neurological diseases like hereditary spastic paraplegia and amyotrophic lateral sclerosis. ${ }^{66}$

WES has been an exceedingly popular tool in the past decade for novel disease-causing gene identification. The technology allows unbiased sequencing of nearly all protein-coding regions with high read-depth; however, it generally results in nearly 20,000 single nucleotide variants and small indels for each individual for which the analysis and interpretation require great expertise that limit its widespread use in the clinical setting. ${ }^{63}$ Still, WES is a great tool for an unbiased novel gene hunt since $85 \%$ of all mutations were suggested to cause Mendelian disorders in the protein-coding of $1 \%-2 \%$ of the human genome. ${ }^{67}$ Meanwhile, some research centers perform WGS for families that remain undiagnosed after WES analysis, though WGS is more costly compared to WES for novel gene identification. ${ }^{68}$

Third-generation sequencing, also called large fragment singlemolecule sequencing, is currently the most advanced sequencing technology. ${ }^{60}$ This technology does not require fragment amplification and allows the long molecule sequencing (up to $30-50 \mathrm{~kb}$ ) in a single run instead of clusters of amplified short DNA sequences. This helps avoid the problems that arise from GCrich region amplification and results in a more evenly distributed coverage along the genome. ${ }^{69}$ This technology is not yet widely common due to high cost and novelty; however, it is likely to identify novel causative genes/mutations and non-conventional disease mechanisms in CMT disease, especially in regions that are poorly covered by short-read sequencing technologies, including non-coding DNA sequences, large deletions, insertions, repeat sequences, inversions, and translocations. ${ }^{70}$

Genetic diagnosis success in CMT disease has rapidly increased as the gene discovery rate accelerated following the development of high-throughput sequencing technologies. ${ }^{4}$ Genetic diagnosis rate ranges from $18 \%$ to $31 \%$ in studies that used gene panels ${ }^{61,64,65,71}$, whereas $45 \%$ to $60 \%$ in studies that utilize WES. ${ }^{16,20,54,72}$ One striking observation is the great diagnostic gap between demyelinating and axonal CMT. For instance, a study published by Inherited Neuropathy Consortium (INC) reviewed 1652 patients from 13 INC centers and revealed a total genetic diagnosis rate of $60.4 \%$; however, the diagnosis rate was $91.4 \%$ 
in CMT1 cases, whereas $42 \%$ in CMT2 cases. ${ }^{73}$ Likewise, another study on 1206 patients from Germany reported genetic diagnosis success in $56 \%$ of CMT 1 cases and $17 \%$ in CMT2 cases. ${ }^{53}$ The total genetic diagnosis rate was $47 \%(302 / 645)$ in our cohort; however, not all patients in the cohort could be analyzed by WES. Sequential sequencing was used for selected cases based on clinical data and pedigree analysis. Still, the GJB1 mutations constitute $10 \%$ of cases (47/459), reflecting the use of a correct strategy in testing for the relevant genes. The genetic diagnosis was possible in approximately 56\% (257/459) in demyelinating (CMT1 and CMT4) and 24\% (45/186) in axonal forms (CMT2 and ARCMT2), in line with the report from Germany. The strategy also helped to unravel novel genes in our cohort, including MFN2 and SH3TC2, HINT1, FGD4, MCM3AP, and AHNAK2, and a novel phenotype segregating with a homozygous missense mutation in the $F X N$ gene. ${ }^{23,27,74-78}$

The missing heritability indicates the disease-causing genes yet to be identified, especially in CMT2, and non-Mendelian aspects of CMT disease, such as modifier genes and multigenic inheritance, that may be uncovered in the future.

\section{Treatment}

No proven efficient therapy for CMT is available. Clinical trials are compelling to design due to the rather slow progression and the heterogeneity of the disease. Nonetheless, several still ongoing trials are promising, of which most are focused on CMT1A as the most frequent form. These studies aimed to reduce the PMP22 expression to overcome the effects of CMT1A duplication.

Progesterone is known to increase PMP22 expression and ascorbic acid enhances myelination. ${ }^{79,80}$ Thus, progesterone antagonists and ascorbic acid are known to be the first candidates for CMT1A treatment. Several transgenic mouse models that overexpress PMP22 have been developed and testing these molecules gave promising results; however, human trials have failed to reproduce these results. ${ }^{81,82}$ Antisense oligonucleotide suppression of PMP22 mRNA levels in CMT1A and gene replacement therapy in loss-of-function mutations are recent emerging therapies. ${ }^{83}$ Another therapeutic approach to lower the toxic PMP22 gene overexpression PXT3033 molecule is used in combination with gamma aminobutyric acid-B receptor agonist baclofen, opioid receptor antagonist naltrexone, and intracellular metabolite D-Sorbitol. ${ }^{84}$ Neurotrophin-3 (NT-3) has been shown to enhance axonal regeneration along with associated myelination in animal models. ${ }^{85}$ AAV1.NT-3 surrogate gene therapy phase $1 / 2$ a clinical trial is underway to improve nerve regeneration in CMT1A. ${ }^{86}$

Several other mouse models are produced to develop novel treatment options. Niacin-mediated Tace activation in a mouse model was shown to ameliorate CMT neuropathies with focal hypermyelination such as CMT4B1 and HNPP. ${ }^{87}$ Another study of a mouse model with CMT1A revealed Curcumin to restore myelinated axons. ${ }^{88} \mathrm{~A}$ small molecule acting as MFN2 agonist in CMT2A and intrathecal gene therapy for different GJB1 mutations were also designed and are currently tested. ${ }^{89,90}$
In conclusion, gene therapy approaches to deliver different therapeutic molecules to patients in different ways or silencing the genes with allele-specific oligonucleotides are all promising therapies that are expected to be successful shortly. Having some of such therapeutic products in the market for neurological disorders, such as spinal muscular atrophy, increases the expectations for other similar disorders and CMT. Unraveling the mutated gene in each CMT patient is necessary to choose one of these personalized treatment options as a preliminary step. Genetic diagnosis should start with CMT1A duplication, followed sequentially with $M P Z$ and GJB1 in demyelinating CMT in Europe and the United States. However, populations with a high rate of consanguinity also need to consider SH3TC2, GDAP1, and HINT1 genes after excluding CMT1A duplication in families with probable recessive inheritance. Today, approximately $60 \%$ of patients with CMT can get a genetic diagnosis, even though approximately 100 IPN genes have been identified. This finding implicates the need to use more advanced techniques in genetic diagnosis and identification of further CMT genes, like thirdgeneration sequencing approaches.

Author Contributions: Concept - A.C., Y.P., E.B.; Design - A.C., Y.P., E.B.; Data Collection and/or Processing - A.C., Y.P., E.B.; Analysis and/or Interpretation - A.C., Y.P., E.B.; Literature Review - A.C., Y.P., E.B.; Writing - A.C., Y.P., E.B.

Conflict of Interest: The authors have declared that no conflicts of interest exist.

Funding: The studies are funded by TUBITAK project number 215 S 883 and Boğaziçi Research Fund project code 20B01D5.

\section{REFERENCES}

1. Pisciotta C, Shy ME. Neuropathy. Handb Clin Neurol. 2018;148:653-665. [CrossRef]

2. De Jonghe P, Timmerman V, Nelis E, Martin JJ, Van Broeckhoven C. Charcot-MarieTooth disease and related peripheral neuropathies. J Peripher Nerv Syst. 1997;2:370387. [CrossRef]

3. Laurá M, Pipis M, Rossor AM, Reilly MM. Charcot-marie-Tooth disease and related disorders: An evolving landscape. Curr Opin Neurol. 2019;32:641-650. [CrossRef]

4. Timmerman V, Strickland AV, Züchner S. Genetics of Charcot-Marie-Tooth (CMT) disease within the frame of the human genome project success. Genes (Basel). 2014;5:13-32. [CrossRef]

5. Parman Y, Battaloğlu E. Recessively transmitted predominantly motor neuropathies. Handb Clin Neurol. 2013;115:847-861. [CrossRef]

6. Rossor AM, Evans MRB, Reilly MM. A practical approach to the genetic neuropathies. Pract Neurol. 2015;15:187-198. [CrossRef]

7. Skre H. Genetic and clinical aspects of Charcot-Marie-Tooth's disease. Clin Genet 1974;6:98-118. [CrossRef]

8. Barreto LC, Oliveira FS, Nunes PS, et al. Epidemiologic Study of Charcot-MarieTooth Disease: A Systematic Review. Neuroepidemiology. 2016;46:157-165. [CrossRef]

9. Bird TD, Ott J, Giblett ER. Evidence for linkage of Charcot-Marie-Tooth neuropathy to the Duffy locus on chromosome 1. Am J Hum Genet. 1982;34:388394. [CrossRef]

10. Lupski JR, de Oca-Luna RM, Slaugenhaupt S, et al. DNA duplication associated with Charcot-Marie-Tooth disease type 1A. Cell. 1991;66:219-232. [CrossRef]

11. Parman Y, Battaloğlu E, Baris I, Bilir B, et al. Clinicopathological and genetic study of early-onset demyelinating neuropathy. Brain. 2004;127:2540-2550. [CrossRef]

12. Pareyson D, Scaioli, Laurà M. Clinical and Electrophysiological Aspects of CharcotMarie-Tooth Disease. Neuromolecular Med. 2006;8:3-22. [CrossRef]

13. Davis CJ, Bradley WG, Madrid R. The peroneal muscular atrophy syndrome: clinical, genetic, electrophysiological and nerve biopsy studies. I. Clinical, genetic and electrophysiological findings and classification. J Genet Hum. 1978;26:311-349. [CrossRef] 
14. Nave KA, Sereda MW, Ehrenreich H. Mechanisms of disease: Inherited demyelinating neuropathies - From basic to clinical research. Nat Clin Pract Neurol. 2007;3:453464. [CrossRef]

15. Siskind CE, Panchal S, Smith CO, et al. A review of genetic counseling for Charcot Marie Tooth disease (CMT). J Genet Couns. 2013;22:422-436. [CrossRef]

16. Brennan KM, Bai Y, Shy ME. Demyelinating CMT -- what's known, what's new and what's in store? Neurosci Lett. 2015;2:14-26. [CrossRef]

17. Tazir M, Bellatache M, Nouioua S, Vallat JM. Autosomal recessive Charcot-MarieTooth disease: From genes to phenotypes. J Peripher Nerv Syst. 2013;18:113-129. [CrossRef]

18. Mathis S, Goizet C, Tazir M, et al. Charcot-Marie-Tooth diseases: an update and some new proposals for the classification. J Med Genet. 2015;52:681-690. [CrossRef]

19. Chance PF, Alderson MK, Leppig KA, et al. DNA deletion associated with hereditary neuropathy with liability to pressure palsies. Cell. 1993;72:143-151. [CrossRef]

20. Murphy SM, Laura M, Fawcett K, et al. Charcot-Marie-Tooth disease: frequency of genetic subtypes and guidelines for genetic testing. J Neurol Neurosurg Psychiatry. 2012;83:706-710. [CrossRef]

21. Kleopa KA. The role of gap junctions in Charcot-Marie-Tooth disease. J Neurosci. 2011;31:17753-17760. [CrossRef]

22. Tazir M, Hamadouche T, Nouioua S, Mathis S, Vallat JM. Hereditary motor and sensory neuropathies or Charcot-Marie-Tooth diseases: An update. J Neurol Sci. 2014;347:14-22. [CrossRef]

23. Züchner S, Mersiyanova IV, Muglia M, et al. Mutations in the mitochondrial GTPase mitofusin 2 cause Charcot-Marie-Tooth neuropathy type 2A. Nat Genet. 2004;36:449451. [CrossRef]

24. Nicholson GA, Magdelaine C, Zhu D, et al. Severe early-onset axonal neuropathy with homozygous and compound heterozygous MFN2 mutations. Neurology. 2008;70:1678-1681. [CrossRef]

25. Bis-Brewer DM, Fazal S, Züchner S. Genetic modifiers and non-Mendelian aspects of CMT. Brain Res. 2020;1726:146459. [CrossRef]

26. Zimoń M, Battaloğlu E, Parman Y, et al. Unraveling the genetic landscape of autosomal recessive Charcot-Marie-Tooth neuropathies using a homozygosity mapping approach. Neurogenetics. 2015;16:33-42. [CrossRef]

27. Zimoń M, Baets J, Almeida-Souza L, et al. Loss-of-function mutations in HINT1 cause axonal neuropathy with neuromyotonia. Nat Genet. 2012;44:1080-1083. [CrossRef]

28. Peeters K, Chamova T, Tournev I, Jordanova A. Axonal neuropathy with neuromyotonia: There is a HINT. Brain. 2017;140:868-877. [CrossRef]

29. Snipes GJ, Suter U, Welcher AA, Shooter EM. Characterization of a novel peripheral nervous system myelin protein (PMP- 22/SR13). J Cell Biol. 1992;117:225-238. [CrossRef]

30. Greenfield S, Brostoff S, Eylar EH, Morell P. Protein Composition of Myelin of the Peripheral Nervous System. J Neurochem. 1973;20:1207-1216. [CrossRef]

31. D’Urso D, Ehrhardt P, Müller HW. Peripheral myelin protein 22 and protein zero: A novel association in peripheral nervous system myelin. $J$ Neurosci. 1999;19:33963403. [CrossRef]

32. Adlkofer K, Martini R, Aguzzi A, Zielasek J, Toyka KV, Suter U. Hypermyelination and demyelinating peripheral neuropathy in Pmp22-deficient mice. Nat Genet. 1995;11:274-280. [CrossRef]

33. Martini R, Zielasek J, Toyka KV, Giese KP, Schachner M. Protein zero (P0)-deficient mice show myelin degeneration in peripheral nerves characteristic of inherited human neuropathies. Nat Genet. 1995;11:281-286. [CrossRef]

34. Fortun J, Go JC, Li J, Amici SA, Dunn WA Jr, Notterpek L. Alterations in degradative pathways and protein aggregation in a neuropathy model based on PMP22 overexpression. Neurobiol Dis. 2006;22:153-164. [CrossRef]

35. Mäurer M, Kobsar I, Berghoff M, Schmid CD, Carenini S, Martini R. Role of immune cells in animal models for inherited neuropathies: facts and visions. J Anat. 2002;200:405-414. [CrossRef]

36. Wang Ip C, Kroner A, Fischer S, et al. Role of immune cells in animal models for inherited peripheral neuropathies. Neuromolecular Med. 2006;8:175-190. [CrossRef]

37. Pareyson D, Saveri P, Sagnelli A, Piscosquito G. Mitochondrial dynamics and inherited peripheral nerve diseases. Neurosci Lett. 2015;596:66-77. [CrossRef]
38. Espinós C, Galindo MI, García-Gimeno MA, et al. Oxidative Stress, a Crossroad Between Rare Diseases and Neurodegeneration. Antioxidants (Basel). 2020;9:313. [CrossRef]

39. Mersiyanova IV, Perepelov AV, Polyakov AV, et al. A new variant of Charcot-MarieTooth disease type 2 is probably the result of a mutation in the neurofilament-light gene. Am J Hum Genet. 2000;67:37-46. [CrossRef]

40. Rebelo AP, Abrams AJ, Cottenie E, et al. Cryptic Amyloidogenic Elements in the 3' UTRs of Neurofilament Genes Trigger Axonal Neuropathy. Am J Hum Genet. 2016;98:597-614. [CrossRef]

41. Verhoeven K, De Jonghe P, Coen K, et al. Mutations in the small GTP-ase late endosomal protein RAB7 cause Charcot-Marie-Tooth type 2B neuropathy. Am J Hum Genet. 2003;72:722-727. [CrossRef]

42. Züchner S, Noureddine M, Kennerson M, et al. Mutations in the pleckstrin homology domain of dynamin 2 cause dominant intermediate Charcot-Marie-Tooth disease. Nat Genet. 2005;37:289-294. [CrossRef]

43. Hinshaw JE. Dynamin and its role in membrane fission. Annu Rev Cell Dev Biol. 2000;16:483-519. [CrossRef]

44. Schafer DA, Weed SA, Binns D, Karginov AV, Parsons JT, Cooper JA. Dynamin2 and cortactin regulate actin assembly and filament organization. Curr Biol. 2002;12:18521857. [CrossRef]

45. Weedon MN, Hastings R, Caswell R, et al. Exome sequencing identifies a DYNC1H1 mutation in a large pedigree with dominant axonal Charcot-Marie-Tooth disease e. Am J Hum Genet. 2011;89:308-312. [CrossRef]

46. Puls I, Jonnauty C, LaMonte BH, et al. Mutant dynactin in motor neuron disease. Nat Genet. 2003;33:455-456. [CrossRef]

47. De Vos KJ, Grierson AJ, Ackerley S, Miller CC. Role of axonal transport in neurodegenerative diseases. Annu Rev Neurosci. 2008;31:151-173. [CrossRef]

48. Evgrafov OV, Mersiyanova I, Irobi J, et al. Mutant small heat-shock protein 27 causes axonal Charcot-Marie-Tooth disease and distal hereditary motor neuropathy. Nat Genet. 2004;36:602-606. [CrossRef]

49. Irobi J, Van Impe K, Seeman P, et al. Hot-spot residue in small heat-shock protein 22 causes distal motor neuropathyy. Nat Genet. 2004;36:597-601. [CrossRef]

50. Kolb SJ, Snyder PJ, Poi EJ, et al. Mutant small heat shock protein B3 causes motor neuropathy: utility of a candidate gene approach h. Neurology. 2010;74:502-506. [CrossRef]

51. Pitceathly RD, Murphy SM, Cottenie E, et al. Genetic dysfunction of MT-ATP6 causes axonal Charcot-Marie-Tooth disease. Neurology. 2012;79:1145-1154. [CrossRef]

52. Fay A, Garcia Y, Margeta M, et al. A Mitochondrial tRNA Mutation Causes Axonal CMT in a Large Venezuelan Family. Ann Neurol. 2020;88:830-842. [CrossRef]

53. Rudnik-Schöneborn S, Tölle D, Senderek J, et al. Diagnostic algorithms in CharcotMarie-Tooth neuropathies: experiences from a German genetic laboratory on the basis of 1206 index patients. Clin Genet. 2016;89:34-43. [CrossRef]

54. Saporta AS, Sottile SL, Miller LJ, Feely SM, Siskind CE, Shy ME. Charcot-MarieTooth disease subtypes and genetic testing strategies. Ann Neurol. 2011;69:22-33. [CrossRef]

55. DiVincenzo C, Elzinga CD, Medeiros AC, et al. The allelic spectrum of CharcotMarie-Tooth disease in. Mol Genet Genomic Med. 2014;2:522-529. [CrossRef]

56. Miller LJ, Saporta ASD, Sottile SL, Siskind CE, Feely SME, Shy ME. Strategy for genetic testing in Charcot-Marie-Disease. Acta Myol. 2011;30:109-116. [CrossRef]

57. Østern R, Fagerheim T, Hjellnes H, Nygård B, Mellgren SI, Nilssen Ø. Diagnostic laboratory testing for Charcot Marie Tooth disease (CMT): the spectrum of gene defects in Norwegian patients with CMT and its implications for future genetic test strategies. BMC Med Genet. 2013;14:94. [CrossRef]

58. Azzedine H, Ravisé N, Verny C, et al. Spine deformities in Charcot-Marie-Tooth $4 \mathrm{C}$ caused by SH3TC2 gene mutations. Neurology. 2006;67:602-606. [CrossRef]

59. Sevilla T, Jaijo T, Nauffal D, et al. Vocal cord paresis and diaphragmatic dysfunction are severe and frequent symptoms of GDAP1-associated neuropathy. Brain. 2008;131:3051-3061. [CrossRef]

60. Slatko BE, Gardner AF, Ausubel FM. Overview of Next-Generation Sequencing Technologies. Curr Protoc Mol Biol. 2018;122:59. [CrossRef]

61. Lupo V, García-García F, Sancho P, et al. Assessment of Targeted Next-Generation Sequencing as a Tool for the Diagnosis of Charcot-Marie-Tooth Disease and Hereditary Motor Neuropathy. J Mol Diagn. 2016;18:225-234. [CrossRef]

62. Cortese A, Wilcox JE, Polke JM, et al. Targeted next-generation sequencing panels in the diagnosis of Charcot-Marie-Tooth disease. Neurology. 2020;94:51-61. [CrossRef] 
63. Pipis M, Rossor AM, Laura M, Reilly MM. Next-generation sequencing in CharcotMarie-Tooth disease: opportunities and challenges. Nat Rev Neurol. 2019;15:644656. [CrossRef]

64. Nam SH, Hong YB, Hyun YS, et al. Identification of Genetic Causes of Inherited Peripheral Neuropathies by Targeted Gene Panel Sequencing. Mol Cells. 2016;39:382388. [CrossRef]

65. Wang W, Wang C, Dawson DB, et al. Target-enrichment sequencing and copy number evaluation in inherited polyneuropathy. Neurology. 2016;86:1762-1771. [CrossRef]

66. Candayan A, Çakar A, Yunisova G, et al. Genetic Survey of Autosomal Recessive Peripheral Neuropathy Cases Unravels High Genetic Heterogeneity in a Turkish Cohort. Neurol Genet. 2021;7:621. [CrossRef]

67. Botstein D, Risch N. Discovering genotypes underlying human phenotypes: Past successes for mendelian disease, future approaches for complex disease. Nat Genet. 2003;33(suppl):228-237. [CrossRef]

68. Choi BO, Koo SK, Park MH, et al. Exome sequencing is an efficient tool for genetic screening of Charcot-Marie-Tooth Disease. Hum Mutat. 2012;33:1610-1615. [CrossRef]

69. Mantere T, Kersten S, Hoischen A. Long-read sequencing emerging in medical genetics. Front Genet. 2019;10:426. [CrossRef]

70. Xiao T, Zhou W. The third generation sequencing: The advanced approach to genetic diseases. Transl Pediatr. 2020;9:163-173. [CrossRef]

71. Yoshimura A, Yuan JH, Hashiguchi A, et al. Genetic profile and onset features of 1005 patients with Charcot-Marie-Tooth disease in Japan. J Neurol Neurosurg Psychiatry. 2019;90:195-202. [CrossRef]

72. Pareyson D, Marchesi C. Diagnosis, natural history, and management of CharcotMarie-Tooth disease. Lancet Neurol. 2009;8:654-667. [CrossRef]

73. Fridman V, Bundy B, Reilly MM, et al. CMT subtypes and disease burden in patients enrolled in the Inherited Neuropathies Consortium natural history study: a crosssectional analysis. J Neurol Neurosurg Psychiatry. 2015;86:873-878. [CrossRef]

74. Candayan A, Yunisova G, Çakar A, et al. The first biallelic missense mutation in the FXN gene in a consanguineous Turkish family with Charcot-Marie-Tooth-like phenotype. Neurogenetics. 2020;21:73-78. [CrossRef]

75. Tey S, Shahrizaila N, Drew AP, et al. Linkage analysis and whole exome sequencing reveals AHNAK2 as a novel genetic cause for autosomal recessive CMT in a Malaysian family. Neurogenetics. 2019;20:117-127. [CrossRef]

76. Ylikallio E, Woldegebriel R, Tumiati M, et al. MCM3AP in recessive CharcotMarie-Tooth neuropathy and mild intellectual disability. Brain. 2017;140:2093-2103. [CrossRef]

77. Stendel C, Roos A, Deconinck T, et al. Peripheral nerve demyelination caused by a mutant Rho GTPase guanine nucleotide exchange factor, frabin/FGD4. Am J Hum Genet. 2007;81:158-164. [CrossRef]
78. Senderek J, Bergmann C, Stendel C, et al. Mutations in a gene encoding a novel SH3/TPR domain protein cause autosomal recessive Charcot-Marie-Tooth type 4C neuropathy. Am J Hum Genet. 2003;73:1106-1119. [CrossRef]

79. Sereda MW, Meyer zu Hörste G, Suter U, Uzma N, Nave KA. Therapeutic administration of progesterone antagonist in a model of Charcot-Marie-Tooth disease (CMT-1A). Nat Med. 2003;9:1533-1537. [CrossRef]

80. Passage E, Norreel JC, Noack-Fraissignes P, et al. Ascorbic acid treatment corrects the phenotype of a mouse model of Charcot-Marie-Tooth disease. Nat Med. 2004;10:396401. [CrossRef]

81. Burns J, Ouvrier RA, Yiu EM, et al. Ascorbic acid for Charcot-Marie-Tooth disease type 1A in children: a randomised, double-blind, placebo-controlled, safety and efficacy trial. Lancet Neurol. 2009;8:537-544. [CrossRef]

82. Morena J, Gupta A, Hoyle JC. Charcot-marie-tooth: From molecules to therapy. Int J Mol Sci. 2019;20:3419. [CrossRef]

83. Zhao HT, Damle S, Ikeda-Lee K, et al. PMP22 antisense oligonucleotides reverse Charcot-Marie-Tooth disease type 1A features in rodent models. J Clin Invest. 2018;128:359-368. [CrossRef]

84. Attarian S, Vallat JM, Magy L, et al. Erratum to: An exploratory randomised doubleblind and placebo-controlled phase 2 study of a combination of baclofen, naltrexone and sorbitol (PXT3003) in patients with Charcot-Marie-Tooth disease type 1A. Orphanet J Rare Dis. 2016;11:92. [CrossRef]

85. Sahenk Z, Nagaraja HN, McCracken BS, et al. NT-3 promotes nerve regeneration and sensory improvement in CMT1A mouse models and in patients. Neurology. 2005;65:681-689. [CrossRef]

86. Sahenk Z, Ozes B. Gene therapy to promote regeneration in Charcot-Marie-Tooth disease. Brain Res. 2020;1727:146533. [CrossRef]

87. Bolino A, Piguet F, Alberizzi V, et al. Niacin-mediated Tace activation ameliorates CMT neuropathies with focal hypermyelination. EMBO Mol Med. 2016;8:1438-1454. [CrossRef]

88. Khajavi M, Shiga K, Wiszniewski W, et al. Oral curcumin mitigates the clinical and neuropathologic phenotype of the Trembler-J mouse: a potential therapy for inherited neuropathy. Am J Hum Genet. 2007;81:438-453. [CrossRef]

89. Rocha AG, Franco A, Krezel AM, et al. MFN2 agonists reverse mitochondrial defects in preclinical models of Charcot-Marie-Tooth disease type 2A. Science. 2018;360:336-341. [CrossRef]

90. Kagiava A, Karaiskos C, Richter J, et al. Intrathecal gene therapy in mouse models expressing CMT1X mutations. Hum Mol Genet. 2018;27:1460-1473. [CrossRef] 